DePauw University

Scholarly and Creative Work from DePauw University

\title{
Rosenkranz's Report on Hegel's Phenomenology of Spirit: A Short Analysis
}

Daniel E. Shannon

DePauw University, deshan@depauw.edu

Follow this and additional works at: https://scholarship.depauw.edu/phil_facpubs

Part of the Philosophy Commons

\section{Recommended Citation}

Shannon, D. (2021). Rosenkranz's Report on Hegel's Phenomenology of Spirit: A Short Analysis. Academia Letters, Article 243. Doi: 10.20935/AL243

This Article is brought to you for free and open access by the Philosophy at Scholarly and Creative Work from DePauw University. It has been accepted for inclusion in Philosophy Faculty publications by an authorized administrator of Scholarly and Creative Work from DePauw University. 


\title{
ACADEMIA $\mid$ Letters
}

\section{Rosenkranz's Report on Hegel's Phenomenology of Spirit: A Short Analysis}

\author{
Daniel Shannon
}

Karl Rosenkranz was the editor-in-chief of Hegel's Collected Works, vols. 1-12(1832-44). He wrote Hegel's Life (1844) as a supplement to these Works. ${ }^{1}$ He has an advantage over most other commentators on Hegel. Not only did he speak with Hegel about his philosophy, but he also had access to his manuscripts, letters, and the recollections of students, family members, and acquaintances. Rosenkranz was himself an adept and prolific philosopher. He is remembered primarily today for his work on Hegel, but in his own right he is still considered for his Encyclopedia of Theological Sciences (1831), Pedagogy as System (1848)-which was translated into English under the title Philosophy of Education (1886)-Aesthetics of the Ugly (1853) and the Science of the Logical Idea (1858). ${ }^{2}$ By virtue of his close ties to Hegel and his own philosophical abilities he appears able to understand and express the complexity and subtly of Hegel's philosophical thought.

His report, while informative and carrying weight, should be read, however, with caution when it comes to Hegel's formative years. He is describing events and compositions that occurred forty years before his report was written, and about a time where the principal proponents of the system of idealism, namely, Hegel and Schelling, later in life did not agree on what had transpired or been intended. ${ }^{3}$ Rosenkranz, at times, seems loose with his descrip-

\footnotetext{
${ }^{1}$ Karl Rosenkranz, "Die phänomeneologische Krisis des Systems bis 1807” in Georg Wilhelm Friedrich Hegels Leben (1844, rpt; Darmstadt: Wissenschaftliche Buchgesellschaft, 1977), 201-15. Hereafter this work will be abbreviated as Hegels Leben followed by page number. All translations from the German texts are my own.

${ }^{2}$ Karl Rosenkranz, Philosophy of Education, trans. by Anna C. Bracket (2nd ed., NY: D. Appleton \& Co., 1886). A complete list of Rosenkranz's publications can be found online: Joachim Butzlaff, "Rosenkranz, Karl," Neue Deutsche Biographie (22) 2005, 70-1, webpage: accessed, 21 December 2020, Deutsche Biographie Rosenkranz, Karl (deutsche-biographie.de).

${ }^{3}$ The best-known instances concern who wrote the "Oldest System Program" (c. 1798) and who was the prin-
}

Corresponding Author: Daniel Shannon, deshan@ depauw.edu Citation: Shannon, D. (2021). Rosenkranz's Report on Hegel's Phenomenology of Spirit: A Short Analysis. Academia Letters, Article 243. 
tions and was not entirely accurate in his dating. We see, even on the first page of his report, his tendency to speak of the lectures, the articles of the Critical Journal (1801-3), the various system projections from 1802-6 as if they were all occurring more or less at the same level of importance. ${ }^{4}$ There are in fact three distinct Jena System Projections, which remain only as draft documents for his lectures at Jena. Only these survive; none of the actual lectures, outside of excerpts provided by Rosenkranz, remain. While the articles clearly reflect Hegel's joint project with Schelling, the lectures, especially those on the history of philosophyand speculative philosophy (philosophical logic), which Rosenkranz relies upon and quotes, were composed after Schelling left Jena in 1803. They show a growing distance between Hegel and his former colleague. Rosenkranz's perspective is, however, from the hindsight of the Berlin period (1818-31), and he tends to ignore the details of Hegel's arguments in order to focus instead on what he believes to be the most important intuitions conveyed by the text.

Despite some problems in his interpretation there are, nonetheless, points that he makes which we should consider authoritative. (1) The Phenomenology arises from a crisis that occurred in the composition of second Jena System Projection, the Logic, Metaphysics, and Natural Philosophy of 1804-5, on the issue of what constitutes the concept of consciousness based upon the dialectic of experience. ${ }^{5}$ (2) The Phenomenology is rooted in the history of philosophy, especially the history of philosophy focused on transcendental idealism, as articulated first by Fichte and then by Schelling; in this regard the book shows how Hegel overcame

cipal author of the Critical Journal article, "Introduction. On the Essence of Philosophical Critique in General," but in more general terms Schelling contended that Hegel developed his system out of Schelling's own. Hegel held, in contrast, that the mature system begins with the Phenomenology, was his own creation, and had little to do with Schelling's projects. Although there is some truth in both accounts, Rosenkranz obviously takes Hegel's side in this dispute, and much of his discussion of the Jena period concerns Hegel's break with Schelling, which Rosenkranz dates from 1804, during the composition of Jena System II. This is shortly after Schelling had left Jena in 1803 for Swabia and, ultimately, forWürzburg but before Hegel began to write the draft Phenomenology circa the spring of 1805 .

${ }^{4}$ Otto Pöggeler points that Rosenkranz misdates some of the earlier manuscript materials, and in some instances, he does not have a proper sense of the early chronology. He remarks that "Rosenkranz did not yet see clearly the development of young Hegel's thought," Hegels Leben, 568.

${ }^{5}$ Rosenkranz says, "Only one additional action was necessary for Hegel to achieve his complete independence [from Schelling]. This was the Phenomenology of Spirit. This entirely new philosophy arises from the concept of self-consciousness. Schelling had... directed subjective idealism to objectivity, where the unity of subject and object was entirely presupposed by him. Hegel sublimated the concept of self-consciousness not simply within the absolute...but within the concept of spirit as a simple moment. Moreover, he sublimated the concept of substantiality that had been continually refashioned under various forms as the limit of self-consciousness. He developed, instead, the concept of experience that constitutes self-consciousness, initially, in his [Jena System II] Introduction to the Logic and Metaphysics. From this project of 1804 the construction of the Phenomenology came to exist, and in it he put the useful results of his studies from that period," Hegels Leben, 202, emphasis is in the original.

Corresponding Author: Daniel Shannon, deshan@depauw.edu

Citation: Shannon, D. (2021). Rosenkranz's Report on Hegel's Phenomenology of Spirit: A Short Analysis. Academia Letters, Article 243. 
these other philosophers' respective expositions of the idealistic system. ${ }^{6}$ (3) There are two distinct sides to spirit: finite spirit, or consciousness, which is the empirically conditioned mind, the concept of which is composed of intellect and will, and infinite spirit, or the absolute, which transcends all empirical limitations. Rosenkranz tells us that absolute spirit emerges when knowledge, as the unity between singular and universal self-consciousness, becomes absolute being. ${ }^{7}$ Knower and known are identical to each other. (4) There are two movements occurring and playing themselves out in the book: one that proceeds empirically and has a linear ascent. It is limited and conditioned by culture and finite experience. The other follows the path of infinite spirit and proceeds circularly to achieve a completed ideality in the system of science. This second path constitutes the transcendence of spirit as absolute knowledge. The first path constitutes the appearance of observing knowledge in finite spirit as a series of stages. Both paths exhibit the development of self-consciousness. ${ }^{8}$ The second path, once free of apparent knowledge, becomes the subject matter of the Science of Logic of 1812-16. It presents the procession of pure ontological categories, which begins from the identity of absolute knowledge with being in the Phenomenology. This way passes beyond the finite shapes of consciousness and is the true essence (Wesen) of absolute spirit. Absolute spirit, since it arises from the stages of finite spirit, still belongs to human experience because it recollects the historical path of consciousness. Its genesis as transcendent being reflects its own historical evolution and transfiguration. The barrier (Schranke) of finitude is transcended in the system because absolute knowledge, or being, which is resurrected from its phenomenological development, has for its epistemic objects the pure entia rationis of philosophical logic. Finally, (6) Rosenkranz contends, against Hegel's detractors, that the Phenomenology is not the prolegomenon to the Logic but is the initial starting point of the system itself. It focuses on the formation of self-consciousness in systematic philosophy. The other parts of the system must always presuppose and follow the accomplishments of the Phenomenology.

In terms of how Hegel composed the book, Rosenkranz identifies the Phenomenology as the blending of world history, philosophy of history, and philosophical logic. This interpre-

\footnotetext{
${ }^{6}$ G. W. F. Hegel, Die Phänomenologie des Geistes, hrsg, Wolfgang Bonsiepen und Reinhard Heede (Hamburg: Felix Meiner Verlag, 1980). Hereafter this work will be abbreviated as PhänG followed by the page number. See Rosenkranz, Hegels Leben, 202-3.

${ }^{7}$ Rosenkranz, Hegels Leben, 212.

${ }^{8}$ Rosenkranz comments that "The absolutely-absolute form [of spirit] is only achieved, however, with the absoluteness of the content; that is, if the movement, without the possibility of progression, permits only a recollected return to the series of progressing shapes. This means that the free presentation of the absolute exits in its unity with self-consciousness. The cognition of this process readily displays, then, not only self-consciousness set by determinate stages of its self-generation, which constitutes the particular shape of knowledge, but also the various matters that have been fixed in it and are necessary to consciousness," Hegels Leben, 203.
}

Corresponding Author: Daniel Shannon, deshan@ depauw.edu Citation: Shannon, D. (2021). Rosenkranz's Report on Hegel's Phenomenology of Spirit: A Short Analysis. Academia Letters, Article 243. 
tation is a contested claim in Hegel scholarship. We can see this issue appearing in the Otto Pöggeler and Hans Fulda debates of the 1960s which, in turn, led to the systematic reading of the Phenomenology by Dieter Henrich, among others, in the 1970s. ${ }^{9}$ The systematic reading tends to discount the importance of the historical motif of Hegel's method. If Rosenkranz is correct, however, then one must accept that Hegel's phenomenological account is a philosophical history. Since Hegel himself says in the book that the Phenomenology is a "detailed history" of the formation of spirit, there is much merit to the claim. ${ }^{10}$

We should note that when Rosenkranz departs from the describing the shapes and movements in the Phenomenology he extols the art of thebook. However, while his claim that the Phenomenology is an "authentic work of art" is no doubt true, this kind of statement is misleading because the implication is that the Phenomenology is foremost a work of literature and not of scientific philosophy. Rosenkranz's intention is to have us believe that Hegel's work is both science and art, and thus it is a triumph of his genius as both a philosopher and writer.

Rosenkranz, as a philosopher, played an important role promoting German Idealism and defending Hegelianism against contemporary critics in the aftermath of Hegel's death in 1831. The hallmark of Rosenkranz's defense of Hegel (against the Left Hegelians, such as, David Strauss, the diatribes of Schopenhauer, and the proponents of Fichte and Herder) ${ }^{11}$ was to advance Hegel's philosophy as a philosophical science against both the traditional religious authorities and the left-leaning radicals. ${ }^{12}$ In general, Rosenkranz sees Hegel as the creator of systematic philosophy who, although engaged in the intellectual controversies of the day, is above all else the champion of understanding philosophy as the science of the whole. Hegel's revolution, according to Rosenkranz, is intellectual because philosophy must be understood as a universal science that embraces all branches of knowledge.

\footnotetext{
${ }^{9}$ See, for instance, Hans Fulda, "Zur Logik der Phänomenologie von 1807," in Hegel in der Sicht der Neueren Forschung, hrsg., Iring Fetscher (Darmstadt: Wissenschaftliche Buchgesellschaft, 1973), 3-34. Dieter Henrich, Hegel im Kontext (1971, rpt; Frankfurt am Main: Suhrkamp Verlag, 1988). Others who support the systematic reading of the Phenomenology include, Johannes Heinrichs, Die Logik der Phänomenologie des Geistes (Bonn: Bouvier Verlag, 1974) and Gerd Kimmerle, Sein und Selbst: Untersuchung zur kategorialen Einheit von Vernuft und Geist in Hegels Phänomenologie des Geistes (Bonn: Bouvier Verlag, 1978).

${ }^{10}$ Hegel says, “The series of shapes, which consciousness acquires on its 'pathway of despair,' is, instead, its detailed history of the formation of consciousness on its way to science," PhänG, 56. Proponents of the historical method include Hans-Georg Gadamer, Hegels Dialetik (Tübingen: J. C. B. Mohr, 1971) and more recently, H. S. Harris, Hegel's Ladder, vols. 1-2 (Indianapolis: Hackett Publications, 1997).

${ }^{11}$ Rosenkranz opposed Arthur Schopenhauer in his On the Characteristic of Schopenhauer's Philosophy (1854) and Rudolf Haym (who wrote an influential criticism of Hegel) in his Apology for Hegel against Dr. Rudolf Haym (1858).

${ }^{12}$ Rosenkranz was a critic of both David Strauss, who was a Left Hegelian, and Friedrich Schleiermacher, who was the founder of the German Evangelical Church. Cf. Rosenkranz, Critique of Schleiermacher's Doctrine of Faith (1836) and Critique of the Principles of the Straussian Doctrine of Faith (1840).
}

Corresponding Author: Daniel Shannon, deshan@depauw.edu Citation: Shannon, D. (2021). Rosenkranz's Report on Hegel's Phenomenology of Spirit: A Short Analysis. Academia Letters, Article 243. 
While advancing Hegel's cause, Rosenkranz also inserts his own comments on how Hegel's compositions could have been improved. ${ }^{13}$ We see this, as well, in his treatment of the Phenomenology when he contends that the accidental character of world-history could have been removed from the book, and that contemporary philosophical problems, which Hegel was interested in solving, became outdated and can now be ignored. He also concedes as a weakness of the book that Fichte's treatment of cognition had already worked out the fundamental structure of consciousness, so that much of what Hegel says in the first three chapters in the Phenomenology is not necessary. Whether or not one agrees with Rosenkranz's appraisals, it is most likely a fair portrait of Hegel and his philosophy from the standpoint of the Berlin period. The idea of philosophy as the science of the whole, which Rosenkranz presents as Hegel's greatest accomplishment, is certainly consistent with the account of philosophy that Hegel gives, for instance, in the Prefaces both to the Phenomenology and Encyclopedia.

\footnotetext{
${ }^{13}$ Cf. Rosenkranz's Critical Elucidation of Hegel's System (1840) and My Reform of Hegelian Philosophy (1852). He wrote the Science of the Logical Idea, vols. 1-2 (1858/59) as the clarification and reformulation of Hegel's Encyclopedia of the Philosophical Sciences (1817-30).
}

Corresponding Author: Daniel Shannon, deshan@depauw.edu Citation: Shannon, D. (2021). Rosenkranz's Report on Hegel's Phenomenology of Spirit: A Short Analysis. Academia Letters, Article 243. 